\title{
BRAF Exon 15 Mutation
}

National Cancer Institute

\section{Source}

National Cancer Institute. BRAF Exon 15 Mutation. NCI Thesaurus. Code C158854.

A molecular genetic abnormality indicating the presence of a mutation in exon 15 of the BRAF gene. 